\section{NEH/NEA appropriations}

Increased funding is being sought for the National Endowment of the Humanities (NEH) and the National Endowment of the Arts (NEA). Library advocates are encouraged to ask their congressional representatives and senators to fund the NEH and NEA at $\$ 150$ million each.

$\mathrm{NEH}$ is requesting $\$ 150$ million for FY2000, an increase of $\$ 40$ million from FY1999. For several years NEH has been funded at $\$ 110$ million. In FY1996 their budget was cut by 36 percent. During a late April hearing before the House Appropriations Subcommittee on the Interior, William Ferris, chair of NEH testified that the extra funds requested for FY2000 would help offset some of that loss. He reminded the subcommittee that next year will mark NEH's $35^{\text {th }}$ anniversary and that this budget request "places particular emphasis on the educational mission of the agency."

$\mathrm{NEH}$ educational programs include teacher seminars and institutes that improve teaching and learning of the humanities, documentary television/films, museum exhibitions, library reading groups, and projects that help out-of-school adults engage in lifelong learning.

Rep. Ralph Regula (R-Ohio), chair of the subcommittee, told Ferris that the reality of tight budget caps this year will make it difficult to give NEH extra funds. Other members on the panel offered positive remarks regarding the job Ferris is doing and stated they would like $\mathrm{NEH}$ to receive the funding requested.

Bill Ivey, NEA chair since 1998 and former director of the Country Music Foundation for 27 years, testified before the subcommittee for the first time. NEA also requested $\$ 150$ million in FY2000, an increase of $\$ 52$ million from FY1999.

"Challenge America" is one of the new major NEA initiatives for the next year. These grants will target communities that lack a sig-

Lynne E. Bradley is deputy executive director of ALA's Washington Office; e-mail: leb@alawash.org nificant arts presence. "Challenge America" builds on key objectives of ArtsREACH, which was set up to strengthen arts activity in the 20 states with the fewest direct NEA grants.

Regula recognized that NEA was striving to become a more accountable agency in how it uses federal funds and distribute grants. He reiterated his statement that the request will be difficult to fulfill due to the tight budget caps.

Although such increases in appropriations are very tough in this climate, there is a bright note. At this writing, a hearing on the reauthorization of NEA/NEH is now scheduled for May 27. There are indications from some congressional representatives that the battles of the past are over and that there is hope for reauthorization occurring.

Action needed: Please contact your members of Congress and ask him or her to fund NEA and NEH at $\$ 150$ million each. Give examples of how you or your college or university have used a grant from one of these agencies. Ask them also to support reauthorization of both endowments. If you need further information regarding congressional appropriations for library programs or other academic programs or about the $\mathrm{NEH} / \mathrm{NEA}$ reauthorization, please contact Mary Costabile, at (800) 941-8478 or e-mail: mrc@ alawash.org.

\section{DMCA concerns rise}

Now that the Digital Millennium Copyright Act (I)MCA) is law, several libraries report receiving threatening letters from content providers citing the DMCA and complaining about infringing activities on the Internet.

These letters have often been specifically addressed to institutions that have registered with the Copyright Office as Online Service Providers (OSPs), and some have been very broad and general in their allegations. In particular, our legal experts advise us that the letters may not be framed appropriately or contain sufficient detail about the claimed infringing sites to qualify as a formal notification requiring action to comply with (continued on page 481) 


\section{ChoiceReviews.online}

More than just reviews, it's a

\section{Reviewing \\ Revolution!}

$\star$ access to some 65,000 reviews via the Internet

$\star$ e-mail notification of new reviews, based on your subject interests

$\star$ searchable database includes all CHOICE reviews since September 1988

$\star$ customized list creation and management

$\star$ SUBSCRIBE NOW for $\$ 325$ - price goes to $\$ 395$ after June 30 !

\section{It's more than just a database of reviews!}

Each subscription to ChoiceReviews.online includes a subscription to CHOICE magazine. We can convert current CHOICE subscriptions to ChoiceReviews.online with full credit for any issues remaining. Call for details.

\section{CHOICE}

100 Riverview Center, Middletown, CT 06457-3445 Phone: (860)347-6933 x33 Fax: (860) 704-0465

For more information: subscriptions@ala-choice.org www.ala.org/acrl/choice 
the database.-Teresa Fishel, Macalester College;fishel@macalester.edu

Google! Search Engine. Access: http:// www.google.com.

Chances are that you have never heard of the Google! search engine. It is not a major player in the Web search engine game, and most of its promotion has had to rely on word of mouth. Too bad, hecause Google! offers powerful searching features, a streamline design, and ease of use that make it a valuable research tool.

At first glance, its simple user interface can be misleading. What goes on behind the scenes of this search engine is actually quite sophisticated. Google! is the outcome of three years of research in Web searching at the Stanford University Computer Science Depart-

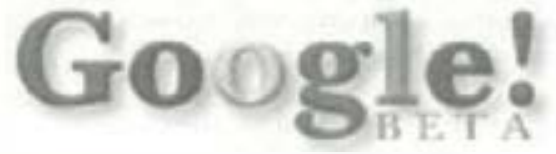

ment by its founclers, Sergey Brin and Larry Page. Each search looks at "over a billion hyperlinks" on the Web to see who is pointing to whom. with the idea that important Web pages point to other important Web pages. The real beauty of Google! though, for librarians who teach users how to search the Web, is in its front-end design and searching features.

The first thing you will notice about Google! is what's not there. No clutter. Unlike Infoseek. Excite, LYCOS, and some of the other major portals, this search engine is lean and clean. There are no unwanted advertisements, teasers, or distracting links, just a simple box for your search query, a couple of buttons, and an option to learn more about Google! and what it can do. That's it.

Like many online library catalogs and periodical indexes, Google! assumes AND between search terms instead of OR. In most other Web search engines, it's the other way around. Google! ignores common words (stopwords) such as "the" and "of," and it does not stem words. If you are searching for colon cancer, you will not retrieve pages dealing with colonies or colonels with cancer, that is. unless they in fact mention colon cancer. Google! is not perfect. It does not offer truncation or true Boolean searching, but it does offer some other nice search features.

Just like with any new search engine, you should always read the help screens before diving in. Google! uses some of the same searching techniques you have come to know when using the advanced search modes in AltaVista, LYCOS, and others. Operators such as the double quotation marks (" ") that allow you to search for bound phrases, and the plus sign ("+") and minus sign ("-") that allow you to require and prohibit terms are all here. There is no "advanced search" mode with Google! The single search mode recognizes all of these operators.

Something unique to Google! is the "I'm Feeling Lucky" button. Clicking this automatically takes you to the first Web page returned for your query. Some students and librarians I know swear by it. The librarian and purveyor of critical thinking in me makes me suspect. You be the judge.

Search engines are getting better. Increasingly, stuclents and other library users want to know how to perform exact Web searches, rather than sift through a thousand or so Web) pages. Search engines like Google! present an alternative to the major commercial portals that cater to less selective users who search the Internet primarily for recreation. Google!'s focus on the searcher and no-nonsense design make it a useful instructional tool for librarians.-Bryan Sinclair, University of North Carolina al Asheville; sincluir@bulldog.unca.edu

(Washington Hotline cont. from page 476) the DMCA safe harbor provisions for OSPs. Of course each institution needs to evaluate these letters on a case-by-case basis as it receives them, and at all times consult its legal counsel when framing its response.

The Office of Information Technology Policy is continuing to monitor the implementation of the DMCA and to develop more detailed interpretations of its very hazy and complex provisions as they evolve. You can help by sending us examples of letters or other contacts citing the act that you may receive from the content providers, as well as letting us know how you responded to them. Contact Rick Weingarten, director of the ALA Office of Information Technology Policy, 1301 Pennsylvania Ave., NW, Suite 403, Washington, I).C. 20004 or phone (800) 941-8478 or e-mail: rww@alawash.org. 